\title{
Analysis of efficiency of regional innovation systems taking into account the financing structure
}

\author{
Anna Akeksandrovna Firsova \\ Faculty of Economics \\ Saratov State University \\ Saratov, Russia \\ a.firsova@rambler.ru
}

\author{
Galina Yuryevna Chernyshova \\ Faculty of Computer Science and Information Technologies \\ Saratov State University \\ Saratov, Russia \\ cherny111@mail.ru
}

\begin{abstract}
The problems of current financing of innovations determine the relevance of the research allowing for quantifying and evaluating the performance of regional innovation systems in terms of the structure of innovation financing. The paper presents an approach to analyzing and evaluating the efficiency of innovation activity in Russian regions using the Data Envelopment Analysis. To estimate the efficiency of regional innovation systems, we use the ratio of a set of input parameters of sources and structure of $R \& D$ financing to a set of output parameters of the innovative goods volume in the context of 80 Russian regions. We rank the regions according to the technical efficiency index, determine the degree of their homogeneity and differentiation, reveal leading and outsider regions by the degree of efficiency of financial resources use in regional innovation systems. It is determined that the share of the leading regions makes $25 \%$ and the share of inefficient regions makes $53 \%$. The conclusion is made on the need to spread the best practices of the leading regions and to apply a more efficient structure for financing innovative activities in outsider regions.
\end{abstract}

Keywords-research and development (R\&D), financing, innovative activity, Data Envelopment Analysis (DEA), technical efficiency

\section{INTRODUCTION}

Modern researchers point out that the competitiveness of the national economy in the modern conditions of globalization is largely dependent on the growth dynamics of regional innovation systems and on the diversified structure of sources of innovative activity financing $[1 ; 2]$.

The problems of determining a balanced and efficient structure for financing innovative activity, a ratio of public and private funds, are relevant for all countries and for all types of economy $[3 ; 4 ; 5]$.

The relevance of studying the mechanisms of innovative activities financing in Russia is conditioned by the insufficiency of privately-owned funds in innovation enterprises and the unavailability of external financing. Search for the mechanisms of sustainable innovation growth in Russia leads to identifying and analyzing the factors of regional innovative development that contribute to improving the efficiency of economic functioning and to developing a hightech meta-technology structure for ensuring sustainable and safe development of the economy in response to global challenges.

The specific features of innovative development in Russia make researchers pay close attention to analyzing the problems of financing innovative activity, since the result of such activity depends largely on financial support. Working out the effective ways of financing innovative activity is currently the most important part of the strategy of Russian economy's innovation development.

The analysis of world practices illustrates different models of innovation financing which correspond to the ways of organizing innovative activity in the country, to the subjects, the scale and the structure of innovation financing, as well as the infrastructure conditions of their implementation. Countries in the head of international competitiveness rankings have a significant share of private financing of research and developments: $66-75 \%$ in the USA, Sweden, Finland, Japan; 56-60\% in the EU countries, Belgium, Germany, France [6]. The third part of domestic investments in R\&D falls to the share of the state budget: $33 \%$ in the EU countries, $28 \%$ in the USA, and $25 \%$ in China. Major share of domestic investments in $\mathrm{R} \& \mathrm{D}$ comes from the private sector, industrial enterprises in particular (over 60\%) [7]. Thus, the experience of developed countries shows that innovative development cannot be totally dependent on the state budget it should also rely on private economic sector's demand for R\&D.

In Russia these indicators differ from those in developed countries. The analysis of sources of innovation financing in the Russian economy reveals a serious disproportion between state $(65 \%)$ and private $(35 \%)$ resources.

The current condition of innovation financing is exacerbated by up-to-date external challenges for Russia and by limited access to international financial markets. Under these conditions, it is impossible to achieve economic growth without revealing reserves and developing new mechanisms for financing innovation enterprises. Therefore today the issues of studying the financial support for structural shifts in the transforming Russian economy are extremely urgent as far as the economy's modernization is concerned. It is necessary 
to give an adequate evaluation of the actual structure and sources of innovation financing and to develop mechanisms for more efficient implementation of such investment activity.

The present paper outlines a comprehensive approach to evaluating the efficiency of innovation activity in the regions of Russia on the basis of indicators which reflect the structure of innovation financing in the regions. The use of modern mathematical models and methods, in particular the method of analyzing the operational environment (Data Envelopment Analysis, DEA), for obtaining quantitative estimates of innovation activity seems to be a relevant tool.

The research purpose is to analyze the efficiency of regional innovation systems using DEA modeling.

The paper outlines and presents solution of the following research tasks:

- selecting a set of indicators which reflect the structure of innovation financing at the regional level in modern Russian conditions;

- applying the model of evaluating the efficiency of regional innovation systems on the basis of Data Envelopment Analysis;

- testing the developed model using the data on sources and structure of financing of 80 regions of the Russian Federation.

\section{MODEL}

Today, DEA models are used to analyze the performance of activities in the process of making management decisions in a variety of areas (industry and agriculture, public administration, finance, information technology, investment) $[10 ; 11]$. The use of DEA in benchmarking technologies for evaluating and comparing the performance of similar objects is associated with the identification of examples of so-called best practices.

In DEA modeling, the methods of mathematical programming are used to evaluate the relative technical efficiency of objects by comparing them with each other, and a Pareto optimal set of points corresponding to effective objects is formed [12]. Technical efficiency is understood as the ratio of a set of input parameters' values to a set of output parameters' values. In the multidimensional space of input and output indicators describing the set of studied objects, a piecewise linear shell - an efficiency boundary - is constructed. The relative efficiency of a particular element from the sampling is determined on the basis of this shell. Thus, the value of a scalar aggregated indicator is calculated for each object in the DEA model.

Formal description of the fundamental DEA model may be presented as follows. Let us have $n$ strategies in the process of decision-making (Decision Making Unit, DMU). Each alternative $D M U_{j}, j=1,2, \ldots, n$, is presented with the set $m$ of input indicators $X_{j}=\left(x_{j 1}, x_{j 2}, \ldots, x_{j m}\right)^{\mathrm{T}}$ and the set $s$ of output indicators $Y_{j}=\left(y_{j 1}, y_{j 2}, \ldots, y_{j s}\right)^{\mathrm{T}}$, which determine the efficiency of a decision.

To estimate the technical efficiency by the DEA method, we need to solve the following task of linear programing:

$$
\begin{aligned}
& \min _{\theta, \lambda}(\theta), \\
& -y_{j}+Y \lambda \geq 0, \\
& \theta x_{j}-X \lambda \geq 0, \\
& \lambda \geq 0,
\end{aligned}
$$

where $X-m \times n$ matrix of input indicators for $n$ alternatives; $Y$ $-s \times n$ matrix of output indicators for $n$ alternatives; $\theta$-scalar quantity, $\lambda$ - vector of scale constants $n$.

The given task is solved for each alternative $D M U_{j}, j=1$, $2, \ldots, n$. Value $\theta, \theta \in(0 ; 1]$, is a measure of $D M U_{j}$ efficiency.

$D M U_{j}$ is considered to be efficient in the DEA model under the condition $\theta=1$. These objects are at efficiency boundary. Based on available data, DEA forms a set of reference objects, as regard to which, $D M U_{j}$ is evaluated as either efficient or inefficient. For inefficient $D M U_{j}$ there is one or several objects at the efficient boundary of a set.

For objects having $\theta<1$, the recommended (target) values of indicators are proposed. Reaching these values will ensure the shift of objects to the efficiency boundary. Estimating the target values of variables for an inefficient object is carried out by projecting this object to the efficiency boundary. The projection is ensured by the presence of the coefficient $\theta$ at the vector $x_{j}$ and the presence of the constraint $\lambda \geq 0$ in the model (1).

\section{RESULTS AND DISCUSSION}

\section{A. Research data}

In the studies of such kind, the choice of input and output variables must meet the criteria for relevance and availability of data. The information base of the present research has been formed on the basis of the Central Statistical Database of the Federal State Statistics Service and the Unified Information System for maintaining the activity of the Ministry of Education and Science of the Russian Federation [8; 9]. To calculate the technical efficiency of regional innovation systems' functioning on the basis of indicators of the innovation financing structure, we use the data on the volume of costs and sources of $\mathrm{R} \& \mathrm{D}$ financing, and carry out sampling from 80 Russian regions.

The method of correlating the result obtained and the costs incurred is considered to be a classical one for efficiency evaluation in economics. This method is used to evaluate the efficiency of innovation activities in the regions.

We may use the ratio of the volume of innovations in the regional context (as one of the adequately statistically measured results of innovation activity) to the domestic R\&D costs of the region (as funds spent to obtain innovative 
products) as one of the determinant indicators allowing to evaluate the condition and efficiency of innovation activity in the region.

Working out a model for evaluating the efficiency of regional innovation systems involves pointing out the input and output factors in a set of indicators that reflect the quantitative structure of financing and the efficiency of regional innovation systems.

Thus, we chose the volume of own-produced innovations (new or technologically modified) as a resulting indicator, which is important for the regional development of the Russian economy, taking into account that the growth in the volume of innovative products is desirable in terms of the application of advanced technologies and their positive impact on the meta-technological structure of the Russian economy.

The input variables characterizing the financing of regional innovation systems, are represented by 9 indicators from available data on the sources and structure of domestic R\&D financing in 80 regions of the Russian Federation for 2015. These indicators were aggregated into 4 main groups that characterize the processes of financing innovation by regions of the Russian Federation. The domestic costs for R\&D are the costs incurred by organizations, including current and capital costs, regardless of the source of funding.

As a result, to construct the DEA model, we propose to use the following indicators as variables:

$\mathrm{Y}$ - volume of innovative products, percentage of the total volume of shipped goods, works performed, services;

X1 - budget funds (funds of budgets of all levels, funds of public sector organizations, budgetary allocations for the maintenance of higher education institutions (higher education sector), funds of higher education institutions), thousand rubles $* 10-1$;

X2 - organizations' proprietory funds for innovative activity, thousand rubles;

X3 - business sector funds for innovative activity, thousand rubles;

X4 - other funds for organizations' innovative activity (non-budgetary funds, funds of private non-for-profit organizations, foreign funds), thousand rubles.

Fig. 1 presents the aggregated information on the federal districts of Russia on the basis of the proposed indicators.

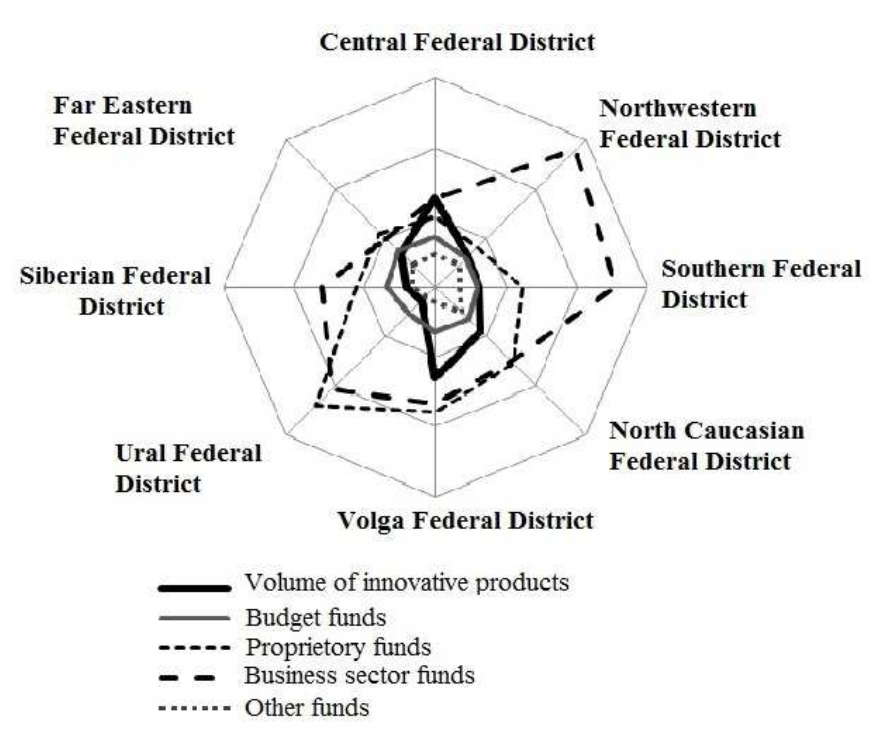

Fig. 1. Share of sources of domestic $R \& D$ financing in the Federal Districts of the Russian Federation.

Visual analysis allows us to draw some conclusions about the efficiency of using financial resources for innovative activities in regional innovation systems. In particular, the Northwestern Federal District and the Southern Federal District, having large amount of financing from the budget, provide a relatively smaller volume of innovative products in comparison to other districts. The Volga Federal District and the Central Federal District, by contrast, provide large volumes of innovative products despite of a smaller amount of funds raised for innovative activities.

A systematic evaluation of innovation activities in the regions on the basis of the proposed set of indicators requires attracting additional funds that would make it possible to carry out a more objective analysis at the regional level. The use of numerical quantitative estimates of efficiency on the basis of the proposed structure of financial indicators allows analyzing the regional innovation activities based on ranking.

\section{B. Building DEA model}

The DEA analysis includes the following types of models: models of evaluating the input efficiency (i.e. efficiency of resources use), so-called input-oriented models; models of evaluating the output efficiency (i.e. output of products or services), so-called output-oriented models; non-oriented models. Model (1) is input-oriented, because the coefficient $\theta$ has influence on the vector of input variables. It should be noted that the input- and output-oriented models evaluate the same limitation and, consequently, identify the DMU set as an efficient one.

DEA models are also differentiated according to the criteria of returns to scale (RTS). As a parameter of RTS, we use such models as constant returns to scale (CRS), variable returns to scale (VRS), non-increasing returns to scale (NIRS), non-decreasing returns to scale (NDRS), generalized returns to scale (GRS) [13,14]. 
To take into account the possibility of variable returns to scale, we need to impose restriction to integral weight coefficients $\lambda$ :

$$
\sum \lambda_{j}=1
$$

As a result of this restriction, a convex linear combination of reference objects is formed.

Further development of approaches to DEA modeling implies the possibility of weakening of condition (2).

Each DEA model implies setting the parameters of RTS output. This characteristic points limits of value range for a sum of vector $\lambda$ elements within the model's boundaries:

$$
L \leq \lambda_{1}+\lambda_{2}+\ldots+\lambda_{j}+\ldots+\lambda_{n} \leq U
$$

where $L(0 \leq L \leq 1)$ and $U(1 \leq U)$ - lower and upper limits for $\operatorname{sum} \lambda_{j}$.

The model of constant returns to scale (CRS) is characterized by the following values of lower and upper limits (3): $L=0, U=\infty$. The model of variable returns to scale (VRS) is characterized by the following values of lower and upper limits: $L=1, U=1$. The model of non-increasing returns to scale (NIRS) is characterized by the following values of lower and upper limits: $L=0, U=1$. The model of nondecreasing returns to scale (NDRS) is characterized by the following values of lower and upper limits: $L=1, U=\infty$. GRS is a generalized model of RTS, which allows for controlling the scale of DMU. GRS also makes it possible to set additional lower and upper limits of $\Sigma \lambda$. In GRS model the values of lower $L(0 \leq L \leq 1)$ and upper $U(U \geq 1)$ limits are estimated by analyst.

Along with the choice of model orientation, the process of DEA modeling implies the choice of scale effect (returns to scale).

We give preference to the input-oriented NIRS model as compared to CRS model, since the latter does not allow us to determine whether $D M U_{j}$ increases or decreases returns to scale.

\section{Results}

Table 1 presents the estimates of technical efficiency for 80 Russian regions.
TABLE 1. DEA-BASED ESTIMATION OF RUSSIAN REGIONS' TECHNICAL EFFICIENCY ACCORDING TO THE STRUCTURE OF FINANCING THE INNOVATIVE

\begin{tabular}{|c|c|c|c|}
\hline DMU & $\begin{array}{c}\text { Technical } \\
\text { efficiency, } \\
\theta\end{array}$ & DMU & $\begin{array}{r}\text { Technical } \\
\text { efficiency, } \\
\theta\end{array}$ \\
\hline Republic of Bashkortostan & 1,0000 & Krasnoyarsk Region & 0,3782 \\
\hline Bryansk Region & 1,0000 & Kurgan Region & 0,3368 \\
\hline Vologda Region & 1,0000 & Kirov Region & 0,3032 \\
\hline Moscow & 1,0000 & Smolensk Region & 0,2962 \\
\hline Nizhny Novgorod Region & 1,0000 & Saratov Region & 0,2879 \\
\hline Novgorod Region & 1,0000 & Belgorod Region & 0,2811 \\
\hline Novosibirsk Region & 1,0000 & Tomsk Region & 0,2555 \\
\hline Penza Region & 1,0000 & Arhangelsk Region & 0,2554 \\
\hline Republic of Kalmykia & 1,0000 & Udmurt Republic & 0,2220 \\
\hline Republic of Mordovia & 1,0000 & Tyumen Region & 0,2202 \\
\hline Republic of Tatarstan & 1,0000 & Republic of Ingushetia & 0,2095 \\
\hline Samara Region & 1,0000 & Altai Krai & 0,1930 \\
\hline Tula Region & 1,0000 & Amur Region & 0,1930 \\
\hline Ulyanovsk Region & 1,0000 & Ryazan Region & 0,1845 \\
\hline Komi Republic & 0,9905 & Republic of Buryatia & 0,1671 \\
\hline Rostov Region & 0,9680 & Kaluga Region & 0,1599 \\
\hline Tambov Region & 0,8788 & Kostroma Region & 0,1579 \\
\hline Moscow Region & 0,8449 & $\begin{array}{l}\text { Jewish Autonomous } \\
\text { Oblast }\end{array}$ & 0,1537 \\
\hline Chuvash Republic & 0,8398 & Murmansk Region & 0,1501 \\
\hline Sakhalin Region & 0,8293 & Volgograd Region & 0,1461 \\
\hline Magadan Region & 0,7779 & Irkutsk Region & 0,1447 \\
\hline Stavropol Region & 0,7405 & Kemerovo Region & 0,1390 \\
\hline Voronezh Region & 0,7202 & Orenburg Region & 0,1181 \\
\hline Khabarovsk Krai & 0,7138 & Pskov Region & 0,1067 \\
\hline Republic of Adygea & 0,6078 & Ivanovo Region & 0,0692 \\
\hline Leningrad Region & 0,6061 & Kamchatka Krai & 0,0652 \\
\hline Transbaikal Krai & 0,5966 & Krasnodar Region & 0,0645 \\
\hline Kabardino-Balkaria & 0,5793 & Sakha (Yakutia) Republic & 0,0624 \\
\hline Kursk Region & 0,5559 & \begin{tabular}{|l|} 
Chukotka Autonomous \\
Okrug
\end{tabular} & 0,0506 \\
\hline Vladimir Region & 0,5553 & Republic of Dagestan & 0,0495 \\
\hline Lipetsk Region & 0,5494 & Karachay-Cherkessia & 0,0482 \\
\hline Mari El Republic & 0,4645 & Oryol Region & 0,0460 \\
\hline St. Petersburg & 0,4620 & Tyva Republic & 0,0454 \\
\hline Yaroslavl Region & 0,4439 & Kaliningrad region & 0,0318 \\
\hline Sverdlovsk Region & 0,4278 & Chechen Republic & 0,0260 \\
\hline Omsk Region & 0,4216 & Primorsky Krai & 0,0214 \\
\hline Chelyabinsk Region & 0,4152 & Republic of Karelia & 0,0118 \\
\hline Perm Krai & 0,4119 & Altai Republic & 0,0060 \\
\hline Astrakhan Region & 0,3836 & Republic of Khakassia & 0,0057 \\
\hline Tver Region & 0,3807 & North Ossetia Alania & 0,0053 \\
\hline
\end{tabular}
ACTIVITIES

Such a distribution of regions to efficient and inefficient by the criterion of innovation activity development is fully consistent with expert estimates.

The DEA method let us rank the regions according to the indicator of technical efficiency. As a result, we have determined the homogeneity of the regions, identified leading and outsider regions in the organization of innovative activities.

The regions with the indicator value $\theta=1$ proved to be the most technically efficient: Moscow, Bryansk region, Vologda region, Nizhny Novgorod region, Novgorod region, Novosibirsk region, Penza region, Samara region, Tula region, Ulyanovsk region, Republic of Bashkortostan, Republic of Kalmykia, Republic of Mordovia, Republic of Tatarstan. These regions demonstrate effective structure and returns to financing the costs of innovation. Their experience should be 
analyzed in detail, studied and disseminated in benchmarking procedures in other regions of Russia.

Fig. 2 presents a histogram for estimating the magnitude and nature of scattered data on the obtained values of technical efficiency in the regions. The diagram shows the frequencies of the regions falling within the indicated ranges of technical efficiency values.

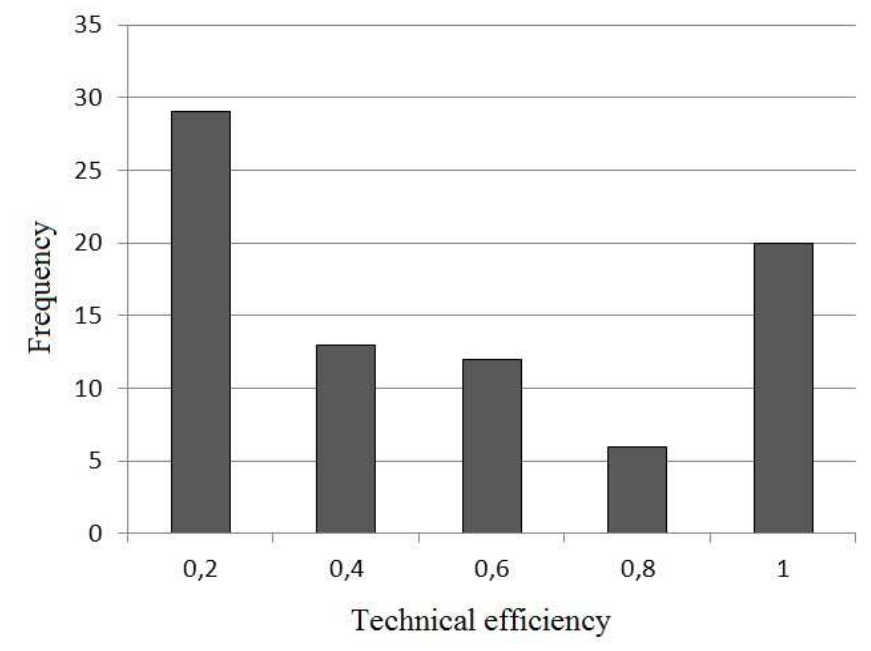

Fig. 2. Grouping of regions according to the efficiency estimates.

The share of leading regions with the value of technical efficiency in the range from 0.8 to 1 , makes $25.0 \%$ (Table 2). It should be noted that the share of inefficient regions with the value of technical efficiency in the range from 0 to 0.4 , amounts to $52.5 \%$. Inefficient regions prevail, so we point out the need for a more rational strategy for financing innovation in these regions.

TABLE 2. GROUPING OF REGIONS ACCORDING TO THE EFFICIENCY ESTIMATES

\begin{tabular}{|c|c|}
\hline Technical efficiency, $\boldsymbol{\theta}$ & Frequency, \% \\
\hline$\theta \in[0 ; 0,2]$ & $36,3 \%$ \\
\hline$\theta \in(0,2 ; 0,4]$ & $16,3 \%$ \\
\hline$\theta \in(0,4 ; 0,6]$ & $15,0 \%$ \\
\hline$\theta \in(0,6 ; 0,8]$ & $7,5 \%$ \\
\hline$\theta \in(0,8 ; 1]$ & $25,0 \%$ \\
\hline
\end{tabular}

Benchmarking technology based on DEA modeling will allow monitoring the level of regions' efficiency in the innovation sector. Analyzing the experience of each leading region and investigating the key parameters of their activities may help us assess the possibility of their application in the current conditions.

The research results can be used for practical purposes to improve regional policy, as well as in strategic planning of innovation activities in the regions.
The proposed approach seems to be one of the mechanisms for elaborating the procedures for macroeconomic planning of options for sustainable innovation development of Russian regions.

The method of DEA analysis can also be used to solve the tasks of identifying the level of trend development of regional innovation depending on the structure of innovation financing and taking into account the heterogeneous specialization of regional economies and the trends of innovative development in the organization of innovation management processes.

Thus, the paper presents a model for estimating the differentiation of the level of innovative development in the Russian regions, depending on the sources of financing for innovative enterprises. This is especially important in the strategic planning of innovative regional strategies and allows for a more rapid response to new information and a more effective implementation of innovation policies in the regions.

The research results can be used in the development of state policy in the field of regional innovation development, in reforming the innovation system at the regional and national level, in the development of mechanisms for attracting investments from the public and private sectors to innovation, in the improvement of legislative documents regulating innovative activity, in the organization of events for activation of the innovation sphere.

The presented model may be used in the activities of public authorities and development institutions in the organization of innovation management processes.

\section{CONCLUSION}

Comparison of regional innovation systems is usually carried out on the basis of integrated socio-economic indicators obtained through multi-criteria methods of system analysis. In the present research we have used the efficiency estimates obtained by the Data Envelopment Analysis (DEA) method as integrated indicators. The results of using the proposed model for evaluating the impact of financing structure on the efficiency of regional innovation systems provide a more detailed and objective data on innovation development in the regions. The application of this approach will allow reducing the subjectivity in the process of making decisions on selecting the sources of innovation financing at the regional level. The identification of regions with the most efficient structure of sources of innovation financing and public administration in the sphere of innovation allows working out an innovative policy at the regional and federal level more objectively. DEA analysis, being an effective tool for modeling a competitive, sustainable and secure socioeconomic development of regions, ensures the productive search for constructive solutions in the management system at the stage of planning and monitoring activities. 


\section{Acknowledgment}

The research is funded by the Russian Fund for Fundamental Research, project 17-32-00050 "Multivariate analysis and modeling of the sources and structure of innovation enterprises financing in the Russian regions".

\section{References}

[1] G. Dosi, C. Freeman and S. Fabiani, "The Process of Economic Development: Introducing Some Stylized Facts and Theories on Technologies, Firms and Institutions," Industrial and Corporate Change, 1994, vol. 3(1), pp. 1-45.

[2] E. C. Wang, "R\&D efficiency and economic performance: A crosscountry analysis using the stochastic frontier approach," Journal of Policy Modeling, 2007, vol. 29(2), pp. 345-360.

[3] K. Blind and H. Grupp, "Interdependencies between the science and technology infrastructure and innovation activities in German regions: empirical findings and policy consequences," Research Policy, 1999, vol. 28 (2), pp. 451-468.

[4] T. Brenner and T. Broekel, "Regional factors and innovativeness: an empirical analysis of four German industries," The Annals of Regional Science, 2011. vol. 47 (1), pp. 169-194.

[5] Z. Griliches, "Issues in assessing the contribution of R\&D to productivity growth". Bell Journal of Economics, 1979, vol. 10(1), pp. 92-116.
[6] R. Camagni and R. Capello, "Regional innovation patterns and the EU regional policy reform: toward smart innovation policies," Growth and change, 2013, vol. 44 (2), pp. 355-389.

[7] P. McCann and R. Ortega-Argilés, "Modern regional innovation policy". Cambridge Journal of Regions," Economy and Society, 2013, vol. 6 (2), pp. 187-216.

[8] The Russian Federal Service of State Statistics [Rosstat]. URL http://www.gks.ru/wps/wcm/connect/rosstat_main/rosstat/en/statistics/sc ience_and_innovations/science/\#

[9] Unified information system for the activities of the Ministry of Education and Science of the Russian Federation [Edinaya informatsionnaya sistema obespecheniya deyatel'nosti Ministerstva obrazovaniya i nauki Rossiiskoi Federatsii]. URL: http://eis.mon.gov.ru/science_innovation/.

[10] J. Liu and L. Lu, "A survey of DEA applications", Omega, 2013, vol. 41(5), pp. 893-902.

[11] K. Tone, Advances in DEA Theory and Applications: With Extensions to Forecasting Models. N.Y.: John Wiley \& Sons, 2017, 576 p.

[12] W. Cooper, L. Seiford and K. Tone, Data envelopment analysis: a comprehensive text with models, applications, references and DEAsolver software. Boston: Kluwer Academic Publishers, 2007, 318 p.

[13] J. Zhu, Quantitative Models for Performance Evaluation and Benchmarking. Data Envelopment Analysis with Spreadsheets. N.Y.: Springer, 2014, $413 \mathrm{p}$.

[14] W. Cook, K. Tone and J. Zhu, "Data envelopment analysis: Prior to choosing model," Omega, 2014, vol. 44, pp. 1-4. 